\title{
THE EFFECTIVENESS OF MANGOSTEEN PEELS EXTRACT AGAINST THE TOTAL OF T LYMPHOCYTES IN HIV PATIENTS
}

\author{
Maria Dyah Kurniasari, Edi Dharmana, Hussein Gasem \\ Department of Fundamental Nursing, Faculty of Medicine and Health Science, Universitas Kristen \\ Satya Wacana, Jalan Kartini No 11 A 50711, Salatiga, Indonesia \\ Email: mariadyah15@gmail.com
}

\begin{abstract}
Introduction: The Province of West Java is one of the highest HIV sufferers in Indonesia that has increased accumulatively in 2013 to 2014. This condition was proven that in 2014 West Java ranked $4^{\text {th }}$ among the provinces with the highest HIV sufferers in Indonesia. HIV has main target to infect a cell that contains of receptor, CD4. CD4 examination routinely is very important to decide HIV replication process. Meanwhile, CD4 test in the laboratory is quite expensive and not always available in every health facilities. Mangosteen peels extract contains of xanthones as an antioxidant, which is needed for body as a prooxidant that can inhibit the replication of HIV and the activity was seen from the total number of lymphocyte. Method: The human experimental research has been done by Randomized Control Group Pretest-Post Test Design. There were 20 patients sample for each group. In group 1, HIV patients with ARV therapy were given mangosteen peels extract and in group 2, they were given placebo capsule. Wilcoxon Smith test and Mann-Whitney U test were used to determine the difference between group 1 and group 2. Result: There is no significant difference between lymphocytes (p: 0.102) to HIV patients with ARV in each group examination. Discussion: The ineffectiveness is caused by the phagocytosis and cytoxity of TNF through the increasing of free radicals in HIV patients.
\end{abstract}

Keywords: Mangosteen peels extract, lymphocytes

\section{INTRODUCTION}

Nowadays, one of the major public health problems for the world is an epidemic of Human Immunodeficiency Virus /HIV infection (Swity et al. 2016). In Indonesia, the number of HIV sufferers is increasing every year. West Java got $4^{\text {th }}$ rank with the highest HIV sufferers among the provinces in Indonesia with the cumulative number of HIV cases: 9340 people, while the number of AIDS patients were reported until 2013 amounted to 4131 people (Spritia Y \& KPA Central Java, 2014). Then, an increasing number of HIV/AIDS people were reported till September 2014 are 13.507 and people with HIV: 4.191.

This retrovirus changes ribonucleic acid (RNA) into deoxyribonucleate acid (DNA) after enter to the host cell. Viral genetic material inserted to the infected DNA cell. The main target is CD4, the cells that have receptors (Nakatani et al. 2002). Therefore, the ARV therapy and CD4 examination routinely in patients are very important to detect HIV viral replication process. Health services such as BJPS has helped people with HIV to get a free CD4 examination, but not all of them get these services (Swity et al. 2016). The CD4 examination is classified into expensive laboratory tests, especially if the examination is required as a routine examination. Moreover, it is not always available at each health facilities. The previous study by Swity (2016) reported that there was a significant correlation between the total numbers of $\mathrm{T}$ cell lymphocytes in patients with HIV in Hasan Sadikin Hospital, Bandung. It shows that the examination $f$ immune cells $(T$ cell lymphocytes) is also important when health facilities are limited (Swity et al. 2016). The reports from previous researchers informed that the elevation of $\mathrm{T}$ lymphocytes total count depicts the level of the immune system (Ghate et al. 2011). It has reported that the total number of $\mathrm{T}$ lymphocytes associated with the level of human body immunity, but the total number of $\mathrm{T}$ lymphocytes in immune relate to HIV patients are still rare. The number of $T$ lymphocytes can replace in monitoring the treatment for HIV patients is not clear enough, but logically the total count of $\mathrm{T}$ lymphocytes had a scientific base in HIV patients immune monitor.

Mangosteen fruit is one of the diversity floras from Indonesia that has a potential to be a medical plant. The skin of mangosteen fruit contains of xanthones as an antioxidant that is needed in human body as a prooxidant balance (reducing radicals, oxidizing radicals, carbon entered, UV light, metal, etc.) that can inhibit the replication of HIV and the activity T lymphocyte as immune 
cells play a role in balancing prooxidant (Chen et al. 1996). The medicinal plants can be adjuvant treatment. Researchers hope mangosteen peel extract as an antioxidant can be used as a complementary medicine jointly with the provision of antiretroviral drugs/ARV. The expectation from this study, there is an effectiveness of mangosteen peel extract to the total number of $\mathrm{T}$ lymphocytes in HIV with ARV therapy, to improve CD4 cell and also improve health services, especially to decrease the risk of co-infection in people with HIV.

\section{METHODS}

Experimental research in human used Double Blind Randomized Pretest-Post Test Control Group Design (HIV patients with antiretroviral therapy in RSUD Gunung Jati, Cirebon, West Java). The total number of respondents were 40 patients, chosen by inclusion and exclusion criteria. 40 patients were divided into 2 groups, treatment group and placebo group. Treatment group was 20 patients who got 90 capsules of mangosteen peel extract for each patient and placebo group was 20 patients who got 90 placebo capsules for each patient. Grouping was done by simple randomized sampling technique. All respondent consumed the capsule 3 times a day (in the morning, in the afternoon, and at night). Researchers also did the blood test twice for both groups. It was before and after getting the treatment for 30 days. The blood test was used to know the total number of lymphocyte differences between treatment group and placebo group.

The results of a descriptive analysis will be presented in tabular form.For identifying the differences between treatment and placebo group, the researcher used MannWhitney test and for pre and post test used Wilcoxon Smith test. Data is considered as a significant difference when the value $(\mathrm{p}<0.05)$ with $95 \%$ confidence level. The study was conducted after obtained approval from Health Research Ethics Committee of Medicine Faculty, University of Diponegoro and dr. Kariadi, Semarang.

\section{RESULTS}

The basic characteristics of research subjects as shown in table 1 describes the same starting point in each group (treatment and placebo).

After determining the data equality and got the result of pre-post test examination, the changes of median value were presented from each group. The data was presented in median value because the data distribution was not normal. Table 2 showed that there was a decline median value in treatment group and placebo. Changes of this data will be the basis for comparative tests between pre and post-test in each group, as well as a comparison between the treatment and placebo group in pre-test and post-test.

Table 1. Characteristics of Basic Research Subjects

\begin{tabular}{|c|c|c|c|c|}
\hline Characteristics & $\begin{array}{l}\text { The total number of } \\
\text { research subjects } \\
(n=40)\end{array}$ & $\begin{array}{c}\text { Treatment } \\
(\mathbf{n}=20)\end{array}$ & $\begin{array}{c}\text { Placebo } \\
(\mathbf{n}=20)\end{array}$ & $\begin{array}{c}\text { Difference test } \\
(p)\end{array}$ \\
\hline Age $( \pm \mathrm{SD})$ & $34,10+5,93$ & $33,25 \pm 5,17$ & $34,95 \pm 6,63$ & 0,464 \\
\hline $\operatorname{Sex}(\%)$ & & & & 0,744 \\
\hline Male & 62,5 & 60 & 65 & \\
\hline Female & 37,5 & 40 & 35 & \\
\hline $\begin{array}{l}\text { The average of CD4 } \\
(\mathrm{mm} 3)( \pm \mathrm{SD})\end{array}$ & $406 \pm 148$ & $373 \pm 28$ & $438 \pm 36$ & 0,172 \\
\hline $\begin{array}{l}\text { Time using ARV (tahun) } \\
( \pm \text { SD) }\end{array}$ & $3,55+2,3$ & $3,1 \pm 2,31$ & $4,0 \pm 2,27$ & 0,135 \\
\hline Weight $(\mathrm{kg})$ & $58,23 \pm 11,11$ & $58,3 \pm 10,6$ & $58,15 \pm 11,87$ & 0,828 \\
\hline $\begin{array}{l}\text { The number of T } \\
\text { Lymphocite (cells } / \mathrm{mm}^{3} \text { ) }\end{array}$ & $2066 \pm 728$ & $1958 \pm 591$ & $2175 \pm 844$ & \\
\hline
\end{tabular}


Table 02. Median Total Lymphocyte Total

\begin{tabular}{ccc}
\hline Groups & Pretest & Post Test \\
\hline Treatment & 1879.50 & 1721 \\
Placebo & 2035 & 2025 \\
\hline
\end{tabular}

The comparative test conducted using Wilcoxon Smith test because the data were not normally distributed and it was tested in pairs. The result after comparative test between pre test and post test in treatment and placebo group confirmed that there was not a significant difference.

Table 3. Wilcoxon Smith Test (The Pre TestPost Test of Treatment and Placebo Group)

\begin{tabular}{cccc}
\hline \multicolumn{2}{c}{ Groups } & $\mathrm{n}$ & $p$ \\
\cline { 1 - 2 } Treatment & Pre Test & 20 & \multirow{2}{*}{0.370} \\
\cline { 1 - 2 } & Post Test & 20 & \\
\hline Placebo & Pre Test & 20 & \multirow{2}{*}{0.794} \\
\hline & Post Test & 20 & \\
\hline
\end{tabular}

After comparative test using Wilcoxon Smith in pre test and post test examination was

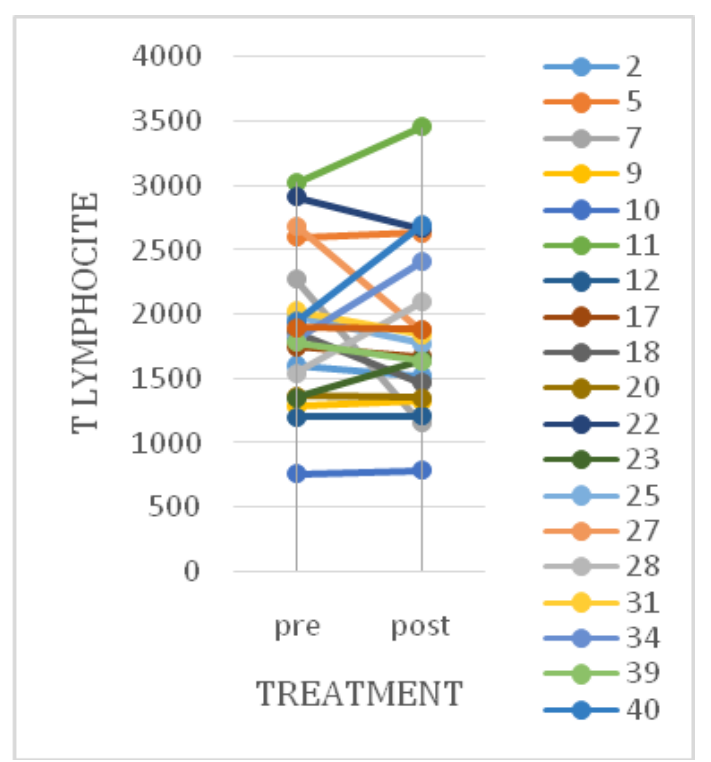

done, the researcher did comparative test using Mann-Whitney to identify the difference between treatment and placebo group as shown in Table 4.

Table 04. Different Mann-Whitney test (Treatment group and placebo)

\begin{tabular}{llcc}
\hline & Groups & $\mathrm{n}$ & $p$ \\
\hline Pretest & Treatment & 20 & \multirow{2}{*}{0.478} \\
& Placebo & 20 & \\
Posttest & Treatment & 20 & 0.102 \\
& Placebo & 20 & \\
\hline
\end{tabular}

It was also necessary to describe the partial distribution of the data from each sample in the following graph. Graph 1 showed that the total lymphocytes count variation changed in each sample. As a result, the fluctuations of each individual in both group changed. It happened because the sample or individual had different multifactor, so the effect of total lymphocytes changing was different from each other.

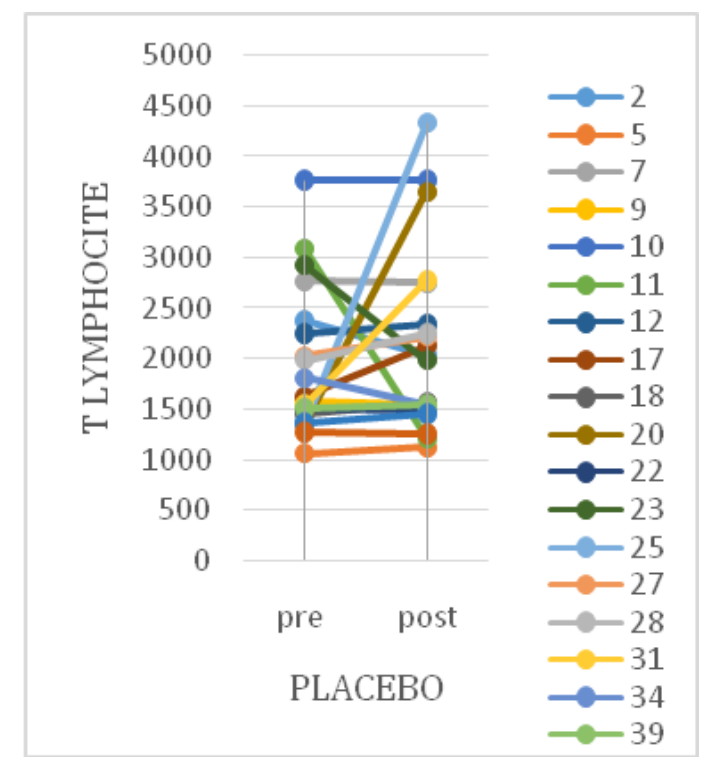

Graph 1. The total of Lymphocytes Individual Graph in Treatment and Placebo Group

\section{DISCUSSION}

The process of HIV infection is $\mathrm{T}$ lymphocytes express CD4 as a surface marker and immune regulation system. CD4 monitoring is commonly done in clinical because it will help to begin giving the ARV and or change different types of antiretroviral 
drugs for patients with HIV. Consuming the ARV correctly will help patients to improve their health status. Moreover, health status will be monitored by immune cells indicators and it will be checked routinely. Delaying on consuming ARV can cause decreasing of CD4 lymphocyte number and it may increase the risk of opportunistic infection (Kaufmann et al. 2003). Besides ARV therapy, the subjects from this study were given mangosteen peel extract as an antioxidant and the researcher hoped that mangosteen peel extract could be as an adjuvant therapy jointly with the provision of antiretroviral drugs. After being given to HIV patients for 30 days, the total lymphocyte examination of pre-test and post-test was not significantly different in the treatment group, by non-parametric Wilcoxon Smith test: $\mathrm{p}=$ 0370 ( $p>0.05)$.

In addition, there was no significant difference in the post-test examination after 30 days consumed mangosteen peel extract between two groups: the treatment and placebo group. This result was shown in Mann-Whitney analysis Table: $p=0478$ ( $>0.05)$. Thus, in this case the mangosteen peel extract was not effective against the total lymphocytes in HIV patients with antiretroviral therapy. The antioxidant in body should be able to contribute or protect against TNF cytokine. This ineffectiveness was possible due to the increasing of free radical production that occurs in people with HIV (Jaruga et al. 2002). The production of free radical increases in HIV patients because phagocytosis process that is done by phagocytic cells and TNF was mediated by target cell. Then, when free radical induced TNF toxicity, it could increase HIV viral replication and destroy CD4 T cells (Kameoka et al. 1993). Unbalancing redox happens because superfluous amount of pro-oxidants or antioxidant reduction that affect normal physiological (Kameoka et al. 1993).

In previous study, there was a positive correlation between total lymphocytes with $\mathrm{T}$ CD4 cells in HIV patients: $r=0.68$ (Swity, 2013).However, in this study, there was no positive association for the results of CD4 T cells increased significantly: $p=0.001(\mathrm{p}$ $<0.005)$. The result of this study showed that many factors could affect the total of lymphocytes count and complete blood test was needed to know the factor that affect of lymphocytes cell. In this study, the subject sampling was human where we know that people have a lot of factor that affect the total of lymphocytes. Although the subject of this study had equal basic characteristic or same starting point based on the statics, but many factors such as daily meal that they consumed, the different daily activities from the research subject were different, the difference of environment, RNA. These factors will have an effect on the general state of the patient. In contrast, if this study was conducted in confounding experimental animals, the factors can be controlled and minimized. As a result, further research is needed with intensity control in general so there are fewer factors that influence the assessment results of research variables. The result of this study could be much better with longer period of treatment and also more research subjects, as well as to minimize other factors that affect the total of lymphocytes.

From HIV form that was provided the researchers also got subjective responses from respondents. Some positive responses that the respondents felt were their appetite increased and they also felt their body healthier. Motivation, support, and attention from others about their feelings and actions can be considered to next study.

\section{CONCLUSION}

Mangosteen peel extract (Garciana mangostana) is not effective against the total lymphocyte count in HIV patient group treated with ARV therapy.

Further research is needed to learn about the development of mangosteen peel extract (Garcinia mangostana) and it is important to study about all of immune cells that contribute to HIV replication, like cytokines, immunoglobulin, CD4 and etc.

\section{REFERENCES}

Chen, S.-X., Wan, M. \& Loh, B.-N., 1996. Active Constituents Against HIV-1 Protease from Garcinia mangostana. Planta Medica, 62(4), pp.381-382. Available at: http://www.ncbi.nlm.nih.gov/pubmed/879 2678 [Accessed May 2, 2017].

Ghate, M. et al., 2011. Mortality in HIV infected individuals in Pune, India. The 
Indian journal of medical research, 133(4), pp.414-20. Available at: http://www.ncbi.nlm.nih.gov/pubmed/21 537095 [Accessed May 2, 2017].

Jaruga, P. et al., 2002. Supplementation with antioxidant vitamins prevents oxidative modification of DNA in lymphocytes of HIV-infected patients. Free radical biology \& medicine, 32(5), pp.414-20. Available at:

http://www.ncbi.nlm.nih.gov/pubmed/118 64781 [Accessed May 2, 2017].

Kameoka, M., Kimura, T. \& Ikuta, K., 1993. Superoxide enhances the spread of HIV1 infection by cell-to-cell transmission. FEBS Letters, 331(1-2), pp.182-186. Available at:

http://doi.wiley.com/10.1016/00145793\%2893\%2980322-L [Accessed May 2, 2017].

Kaufmann, G.R. et al., 2003. CD4 TLymphocyte Recovery in Individuals With Advanced HIV-1 Infection
Receiving Potent Antiretroviral Therapy for 4 Years\&lt;subtitle\&gt; The Swiss HIV Cohort Study\&lt;/subtitle\&gt; Archives of Internal Medicine, 163(18), p.2187. Available at:

http://www.ncbi.nlm.nih.gov/pubmed/145 57216 [Accessed May 2, 2017].

Nakatani, K. et al., 2002. Inhibitions of histamine release and prostaglandin E2 synthesis by mangosteen, a Thai medicinal plant. Biological \& pharmaceutical bulletin, 25(9), pp.113741. Available at: http://www.ncbi.nlm.nih.gov/pubmed/122 30104 [Accessed May 2, 2017].

Swity, A.F., Setiabudi, D. \& Garna, H., 2016. Korelasi Total Lymphocyte Count terhadap CD4 pada anak dengan Infeksi Human Immunodeficiency Virus. Sari Pediatri, 15(2), p.81. Available at: https://saripediatri.org/index.php/saripediatri/article/view/275 [Accessed May 2, 2017]. 